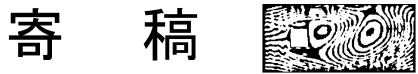

\section{日本風工学会の名誉会員に推挙されて \\ My election as an Honorary Member of the Japan Association \\ for Wind Engineering}

アーサン・カリーム*

Ahsan Kareem
I am very pleased to receive the distinction of being elected as an Honorary Member of the Japan Association for Wind Engineering (JAWE). It is a great honor to be associated with perhaps one of the most active associations around the world related to wind engineering. I had the honor of joining JAWE during my first extend visit to Japan as a Visiting Professor at the University of Tokyo in the spring of 1990. At the occasion of my seminar at the IIS, the University of Tokyo kindly arranged by Prof. S. Murakami, I met several of the JAWE members. I was invited to join the association as a foreign member by then the Treasurer. Prof. Y. Tamura. I remained member for several years and somehow my membership lapsed because as a foreign member we could not benefit from the regular activities of the association. I still believe that the official publication of JAWE, JWE is outstandingly rich with innovative as well practical application papers. Unfortunately they are in Japanese and cannot be of use to non-Japanese! Effort should be made to translate papers into English or an extended summary in English of each paper be included in the appendix!

I look at the roster of the honorary members of JAWE and some of the familiar names are noteworthy who have distinguished themselves as not only leaders of wind engineering in Japan, but also worldwide! I was equally thrilled to note that among twenty three elected honorary members there are only three foreign members. I feel much honored to join this small group involving late Prof.
A.G. Davenport and Mr. R. L. Wardlaw!

I look forward to attending the annual meeting of JAWE and meet most of the members in person to make new acquaintances and visit with old friends and colleagues. I thank you again the Board of Directors of JAWE to bestow this honor for which I am very indebted to each individual member. 